Maurice A. Deane School of Law at Hofstra University

Scholarly Commons at Hofstra Law

Hofstra Law Faculty Scholarship

7-22-2014

\title{
Hard Labor: New Pregnancy Discrimination Guidance From the EEOC
}

Joanna L. Grossman

Maurice A. Deane School of Law at Hofstra University

Follow this and additional works at: https://scholarlycommons.law.hofstra.edu/faculty_scholarship

Part of the Family Law Commons

\section{Recommended Citation}

Joanna L. Grossman, Hard Labor: New Pregnancy Discrimination Guidance From the EEOC Verdict (2014) Available at: https://scholarlycommons.law.hofstra.edu/faculty_scholarship/355

This Article is brought to you for free and open access by Scholarly Commons at Hofstra Law. It has been accepted for inclusion in Hofstra Law Faculty Scholarship by an authorized administrator of Scholarly Commons at Hofstra Law. For more information, please contact lawlas@hofstra.edu. 


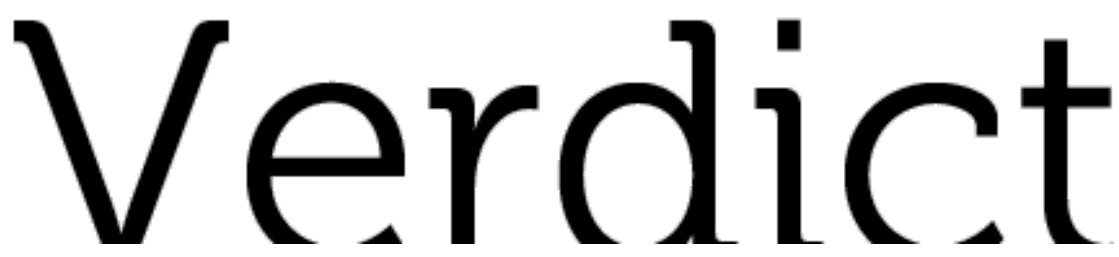

July 22, 2014

Joanna L. Grossman

\section{Hard Labor: New Pregnancy Discrimination Guidance From the EEOC}

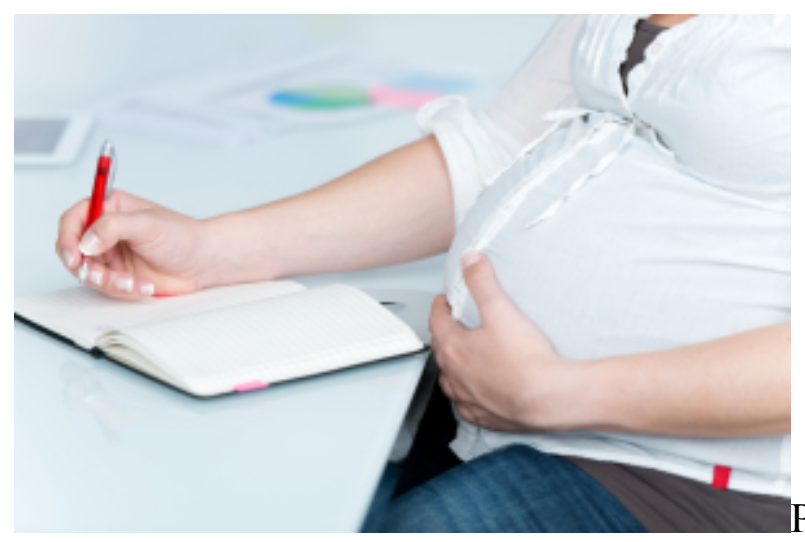

Pregnancy discrimination in the workplace is an intractable problem, one that has resulted in a startling number of claims each year to the Equal Employment Opportunity Commission (EEOC) - rising at a faster rate (http:/qualitycarenow.nationalpartnership.org/site/DocServer/\%20Pregnancy_Discrimination_Act_-

Where We Stand 30 Years_L.pdf?docID $=\mathbf{4 2 8 1}$ ) than women are joining the workforce - and increased media attention. But it has also led to extensive litigation that raises, in a variety of contexts, the question of what constitutes illegal pregnancy discrimination under federal law.

In light of these developments, the EEOC has just issued new Enforcement Guidance (http://www.eeoc.gov/laws/guidance/pregnancy_guidance.cfm) on pregnancy discrimination—its first in several decades - to explain its interpretation of applicable statutes. In this column, I'll explain key aspects of the guidance, along with its relevance to Young v. UPS, a pregnancy discrimination case that the U.S. Supreme Court has just agreed to hear.

\section{Federal Protection Against Pregnancy Discrimination at Work}

The heart of pregnancy discrimination law is the Pregnancy Discrimination Act (PDA) of 1978, signed into law by President Jimmy Carter in response to a bizarre 1976 opinion from the U.S. Supreme Court, General Electric v. Gilbert (http://supreme.justia.com/cases/federal/us/429/125/), in which it held that pregnancy discrimination was not a form of sex discrimination under Title VII of the Civil Rights Act of 1964, the main federal antidiscrimination law. This ruling, along with others, left in place a regime in which public and private employers could openly discriminate against pregnant women by refusing to hire them, forcing them to quit upon becoming pregnant, refusing to accommodate the physical effects of pregnancy, or changing the conditions of employment to suit the needs of the employer. (More details on the developments leading up to the PDA are available here (http://verdict.justia.com/2013/10/29/pregnancy-discrimination-act-reaches-advanced-maternal-age).)

The PDA was designed to disrupt the status quo - to open workplace doors to pregnant women, and to force employers to abandon those policies and practices that falsely stereotyped pregnant women as incompetent or reflected normative assumptions about the impropriety of pregnant women or mothers in the workforce.

The first clause of the PDA amended Title VII to make clear that discrimination on the basis of "pregnancy, 
childbirth, or related medical conditions" is unlawful as a form of sex discrimination under Title VII-expressly repudiating the holding in Gilbert. This eliminated the most common exclusionary policies (e.g., pregnant school teachers must leave by the fourth month of pregnancy) and provided a basis for challenging employment decisions based on bias against pregnant women or the application of stereotypes about their competence, abilities, or proper place.

The second clause, which provides that pregnant women have the right to be treated the same as others who are "similar in their ability or inability to work," was designed to provide a comparison group by which pregnant woman could gauge their right to benefits or accommodations. Pregnant women have no absolute right to accommodations, but if temporarily disabled workers receive them, then pregnant workers are entitled to them as well. Moreover, under a 1987 ruling from the Supreme Court in California Federal Savings v. Guerra (http://supreme.justia.com/cases/federal/us/479/272/), the second clause provides a floor but not a ceiling on benefits and accommodations, so employers can choose to treat pregnant workers more favorably than comparably disabled workers. The second clause, however, has been routinely misinterpreted and misapplied by lower courts, leading to both great confusion about its scope and meaning and a dilution of the rights Congress intended to bestow.

By its terms, the second clause of the PDA provides, at best, a comparative right of accommodation. It does not give pregnant women any absolute right to have pregnancy-related disability accommodated with leave or modifications to the job. Instead, it creates a comparison group to whom pregnant women can compare themselves to gauge their possible entitlement to an accommodation. If no one gets benefits or accommodations, pregnant women have no right to them either. But, the straightforward language of the second clause would suggest, if temporarily disabled workers receive accommodations, then pregnant women must also receive them.

\section{The EEOC's New Enforcement Guidance: What Is "Pregnancy"?}

The EEOC Guidance first tackles the question that has plagued courts of what falls within the category of "pregnancy, childbirth, and related medical conditions." Work can potentially conflict with all aspects of the reproductive process. Lawsuits have raised specific questions about whether discrimination on the basis of contraceptive coverage, infertility, and lactation fall within the PDA. Confusion about the proper scope has led to some sensible rulings - like the Seventh Circuit's ruling in (http://writ.news.findlaw.com/grossman/20080819.html) Hall v. Nalco that discrimination against a female employee because she was seeking fertility treatment is actionable - and some mysterious ones-like that of a federal district court in EEOC v. Houston Funding holding that (http://verdict.justia.com/2012/02/21/a-federal-judge-thwarts-title-vii-and-the-pregnancy-discriminationact-by-ruling-bizarrely-that-lactation-is-not-related-to-pregnancy) lactation discrimination is not covered because lactation is not related to pregnancy.

The Guidance takes an appropriately broad approach to defining discrimination under the PDA, given the text of the statute and the Supreme Court's prior opinions. While an employer is not liable for pregnancy discrimination if the woman's condition was neither revealed nor obvious, it is liable for adverse decisions based on stereotypes or assumptions about a pregnant woman's capacity to work, as well as for decisions motivated by a past pregnancy. Even before a pregnancy occurs, employers cannot discriminate on the basis of potential pregnancyfertility - or reproductive risk. They also cannot discriminate on the basis of a woman's intentions to become pregnant, nor her seeking of fertility treatment to become pregnant. This does not mean that employers must facilitate employee efforts to become pregnant - it tacitly approves court decisions holding that the exclusion of fertility treatments from employer-provided insurance does not violate Title VII-but only that they cannot single out or punish employees based on false assumptions about how an existing or future pregnancy might impact a woman's capacity to work or because of animus against an employee who has made these decisions. Employers must also, under the second clause of the PDA, provide leave, benefits, or accommodations for these conditions to at least the same degree it provides them for comparable medical conditions.

The Guidance also weighs in on contraception, an issue that has been controversial under discrimination law and also in recent litigation about Obamacare. In the Guidance, the EEOC concludes, as several federal courts have, that an employer's exclusion of prescription contraceptives - all of which are used by women only-from an otherwise comprehensive insurance plan constitutes illegal sex discrimination. With respect to lactation, the 
Guidance concludes that discrimination against an employee because she is breastfeeding is actionable and that the comparative right of accommodation means that employers must accommodate lactation at least to the same degree they accommodate similar medical conditions. (In addition to having rights under Title VII, women have rights under Obamacare to reasonable break time and a private place to pump breastmilk.) Finally, although the PDA expressly states that employers do not have to provide insurance coverage for abortion, the Guidance concludes that they cannot take adverse action against a woman for seeking an abortion, nor encourage her to get one in order to keep her job.

\section{The Enforcement Guidance and Discriminatory Light-Duty Policies}

A second key question covered by the Guidance relates to an employer's failure to accommodate pregnancyrelated incapacity despite accommodating similar incapacity for at least some other workers. In the last decade, there have been a number of lawsuits raising questions about the scope and meaning of the second clause of the PDA. The focus of these lawsuits has been the legality of employer policies that provide light-duty assignments to workers who are injured or disabled on the job (and sometimes to other groups of workers as well), but not to those who are injured off the job. (Lawsuits of this type are discussed here

(http://writ.news.findlaw.com/grossman/20060613.html), here

(http://writ.news.findlaw.com/grossman/20060627.html), here (http://verdict.justia.com/2013/10/29/pregnancydiscrimination-act-reaches-advanced-maternal-age) and here (http://verdict.justia.com/2014/04/01/undue-burden).) These policies do not, by their words, exclude pregnancy, but they are drawn in a manner such that workers with pregnancy-related disability cannot obtain light-duty accommodations. This is so even when the workers who do receive light-duty accommodations are, in every way, "similar [to pregnant women] in their ability or inability to work."

Yet, despite the obvious violation of the PDA's second clause, several federal appellate courts have upheld lightduty policies of this nature. Taking a misguided approach to the PDA, courts have searched for discriminatory intent rather than seeing the policy itself as a formal policy of facial discrimination. The most egregious case is Young v. UPS (http://law.justia.com/cases/federal/appellate-courts/ca4/11-2078/11-2078-2013-01-09.html), in which the Fourth Circuit acknowledged that it was collapsing the first and second clauses of the PDA and requiring discriminatory intent for all claims of pregnancy discrimination.

In that case, Peggy Young, a delivery driver who carried lighter letters and packs for United Parcel Service, had a lifting restriction during pregnancy. UPS decided that it could not continue to allow her to work unless she could lift the amount listed in her job description, even though she rarely if ever was asked to lift things that heavy. She was denied a light-duty accommodation despite a combination of collective bargaining rights and employer policies that provided light duty assignments for employees who were injured on the job, who had a qualifying disability under the ADA, or who were legally prohibited from driving due to causes as varied as complications from diabetes and a lost license due to a conviction for driving while intoxicated.

Both the trial and appellate courts held that UPS had not violated the PDA because the policy did not exclude only pregnancy, and there were at least some temporarily disabled employees who, like her, needed accommodation but would not receive it. The Fourth Circuit, inexplicably, rejected the notion that the second clause of the PDA creates a "distinct and independent cause of action," despite several Supreme Court cases treating it in that way, and refused to transform "an antidiscrimination statute into a requirement to provide accommodation to pregnant employees, perhaps even at the expense of other, nonpregnant employees."

The type of reasoning upon which the Fourth Circuit relied is the death knell for the right of comparative accommodation. It effectively allows employers to revert to a pre-PDA world, in which they can single out pregnancy from among other disabilities for adverse treatment. This is precisely what the PDA was enacted to eliminate. (The Supreme Court recently agreed to review this ruling, and it will be argued next term.)

The new EEOC Guidance, fortunately, tackles the light-duty issue head on. It concludes that a pregnant worker "may still establish a violation of the PDA by showing that she was denied light duty or other accommodations that were granted to other employees who are similar in their ability or inability to work." Comparative evidence that pregnant workers are treated worse than others similar in their ability or inability to work, as a matter of 
policy or actual practice, is sufficient to establish a violation of the PDA whether or not the employer bore animus against pregnant workers. Therefore, the plaintiff need not use pretext analysis to smoke out discriminatory intent. A policy or decision that denies light duty to a pregnant worker while making it available to someone injured on the job or someone with a qualifying disability under the ADA is prima facie evidence of discrimination.

Moreover, the Guidance continues, "an employer cannot lawfully deny or restrict light duty based on the source of a pregnant employee's limitation. Thus, for example, an employer must provide light duty for pregnant workers on the same terms that light duty is offered to employees injured on the job who are similar to the pregnant worker in their ability or inability to work." This is an important response to the appellate court rulings, including the one in Young, which have held that discrimination based on source of injury is "pregnancy-neutral" as long as pregnancy is not the only condition excluded.

If these interpretations were followed in Young, as they should be, the Supreme Court would reverse the Fourth Circuit's ruling. Peggy Young clearly suffered actionable pregnancy discrimination, for which she should be entitled to a remedy.

\section{Conclusion}

The new EEOC guidance tackles other issues related to pregnancy discrimination as well: the proper use of disparate impact theory, the impropriety of forced leave policies, and, importantly, the interaction between other federal statutes such as the Family and Medical Leave Act and the Americans with Disabilities Act (including the latter's 2008 amendments). Across the board, the EEOC takes an approach designed, as Congress intended, to allow pregnant women to begin work, continue working, and return to work throughout the reproductive process. The Guidance shows sensitivity to the most common types of employer policies and practices that continue to stymie the careers of women who have been or might be pregnant, and it urges employers to go beyond even what the law requires where necessary to level the playing field. Were employers to both comply with the law and follow the recommended "best practices," pregnant women would find a very different workplace indeed.

Joanna L. Grossman, a Justia columnist, is the Sidney and Walter Siben Distinguished Professor of Family law at Hofstra University. She is the coauthor of Inside the Castle: Law and the Family in 20th Century America (Princeton University Press 2011), co-winner of the 2011 David J. Langum, Sr. Prize for Best Book in American Legal History, and the coeditor of Gender Equality: Dimensions of Women's Equal Citizenship (Cambridge University Press 2009). Her columns focus on family law, trusts and estates, and sex discrimination. Follow @JoannaGrossman

Tags Legal

Posted In Civil Rights, Employment Law

Access this column at http://j.st/ZQJY

(C) 2011-2014 Justia :: Verdict: Legal Analysis and Commentary from Justia ::

\section{JUSTIA}

The opinions expressed in Verdict are those of the individual columnists and do not represent the opinions of Justia

Have a Happy Day! 